\title{
VIEWPOINT
}

\section{Intensive care sedation: the past, present and the future}

\author{
Yahya Shehabi*1, Rinaldo Bellomo², Sangeeta Mehta ${ }^{3}$, Richard Riker ${ }^{4}$ and Jukka Takala ${ }^{5}$
}

\begin{abstract}
Despite the universal prescription of sedative drugs in the intensive care unit (ICU), current practice is not guided by high-level evidence. Landmark sedation trials have made significant contributions to our understanding of the problems associated with ICU sedation and have promoted changes to current practice. We identified challenges and limitations of clinical trials which reduced the generalizability and the universal adoption of key interventions. We present an international perspective regarding current sedation practice and a blueprint for future research, which seeks to avoid known limitations and generate muchneeded high-level evidence to better guide clinicians' management and therapeutic choices of sedative agents.
\end{abstract}

\section{Intensive care sedation: past, present, and future}

The administration of sedative drugs is an almost universal intervention in mechanically ventilated intensive care unit (ICU) patients [1]. One might, therefore, expect that there is a strong body of epidemiologic knowledge about the use of such drugs to guide clinicians' current practice and therapeutic choices. However, despite a noticeable evolution in the field over the last 10 years, this is not the case [2-4]. One might also reasonably expect that there are multiple double-blind or open-label large (>1,000 patients) multicenter randomized controlled trials to guide clinicians in their choice of optimal therapy. This is also not the case. Furthermore, existing evidence has not been widely implemented [4].

There are several reasons for this. First, individual patient variability mandates dynamic and frequent changes in drug selection and dose in response to changing

\footnotetext{
*Correspondence: y.shehabi@unsw.edu.au

'University of New South Wales Clinical School, Prince of Wales Hospital,

Barker Street, Randwick, NSW 2035, Australia

Full list of author information is available at the end of the article
}

clinical situations $[2,3]$. Second, sedation is often undertaken by using a combination of drugs (benzodiazepines, propofol, narcotics, $\alpha_{2}$ central receptor agonists, enteral sedatives, and antipsychotics), and each is administered dynamically in response to perceived and target sedation and analgesia. This additional layer of complexity makes trial design even more difficult and blinding of an intervention almost impossible. Third, the premise of many studies that achieving a given target level of sedation with one sedative versus another is not widely accepted as a means to achieve different clinical outcomes. Fourth, there is significant variability in the intensity of ICU nursing and medical bedside care and subsequently in sedation practices worldwide [4], making research findings in one context difficult to interpret and generalize. Finally, there is uncertainty about how best to diagnose delirium [5,6], a major outcome in most sedation studies. In this level-I data-poor environment, strong opinions abound, creating additional obstacles to the generation of higher-level evidence and the implementation of new recommendations.

In this point-of-view article, we seek to provide a global perspective on sedation to address important progress in the field and to highlight recent and imminent developments in high-quality evidence generation.

\section{International sedation guidelines}

In the 1980s and 1990s, sedation practice and drug selection for adult ICU patients were largely an extension of the practice of general anesthesia. Generally, the goal was deep sedation, and neuromuscular blocker use was not uncommon [7]. Because of the paucity of ICU-specific data regarding sedation, the first ICU sedation guidelines published in 1995 contained six recommendations and were based on 13 references [8]. Nevertheless, this pioneering effort recognized that adequate analgesia was a primary goal, that long-term administration of lorazepam had prolonged clinical effects, and that the greater acquisition costs of new sedatives (then midazolam and propofol) were potentially balanced by downstream clinical benefits with short-term use. The 2002 Society of Critical Care Medicine guidelines produced 28 recommendations based on 235 references [9]. This guideline 
included an introduction to the assessment and treatment of delirium and drug-specific recommendations for various time frames and clinical situations. Both the 1992 and 2002 guidelines, however, recognized the dearth of high-quality trials. Though an improvement on the previous guidelines, the 2002 guidelines did not embrace new evidence outside of the US and thus had limited applicability. Hence, a number of country-specific guidelines appeared, reflecting newer information and local practices and matching individual formulary regulations $[10,11]$.

The updated 2013 Society of Critical Care Medicine guidelines provide an unparalleled evaluation and review of the literature (more than 18,000 published articles) with 54 statements and recommendations [12]. Two important recommendations include an emphasis on the analgesia-first concept, or 'analgesia first sedation' [13], and the many benefits resulting from a lighter level of sedation for ICU patients. Additional aspects of the guidelines relate to an expanded understanding of the risk factors for and impact of delirium, and perhaps paradoxically, even more questions are raised about the management of this serious syndrome.

\section{Sedative drugs in intensive care unit sedation}

Many of the current drugs used in ICU sedation were initially introduced for general anesthesia or short-term sedation during regional anesthesia. This is why many of the currently used sedatives and analgesics have never been formally evaluated for safety and efficacy for ICU sedation. This also may explain the poor safety record of some sedative agents and the relatively late discovery of the adverse effects of ICU sedation.

Opioids have been an integral part of caring for critically ill patients since the early days of intensive care. The analgesic and sedative characteristics of morphine have been recognized since the 19th century, when it was used to comfort dying patients. Morphine is widely used in ICUs, and its sedative effects, especially at higher doses, may seem attractive in combining pain relief and sedation. The recent claim that the use of morphine alone represents 'no sedation' is clearly misleading [14], as morphine provides analgo-sedation. The effects, however, of long-term treatment with morphine or morphinebased regimens have not been formally evaluated in ICU patients. Despite well-known adverse effects (histamine release, hypotension, respiratory depression, tolerance and dependence, and accumulation of active metabolites) and long duration of action, morphine is likely to keep its place in the ICU because of familiarity, availability, and cost-effectiveness, at least in comforting dying patients, particularly in cost-restricted settings. Fentanyl is a shorter-acting opiate with no active metabolites; however, like morphine, it has a long context-sensitive half-life and accumulates in renal failure [15]. Although fentanyl has less-sedating effects than morphine, it potentiates the effects of sedative drugs and in high doses can produce somnolence and sedation [16]. Driven by the perceived cardiovascular stability and favorable kinetics $[17,18]$, fentanyl appears to have replaced morphine to a large extent; whether this evolution in practice is clinically beneficial, however, remains untested.

The history of sedative use in the ICU has been long and complex. In the absence of long-term safety data, familiarity with short-term use and its apparent safety profile led to the introduction of etomidate as a continuous infusion for ICU sedation, with resulting adverse events including adrenal suppression and a 19\% absolute increase in mortality in trauma patients $[19,20]$. Benzodiazepines, however, have the longest history and remain the most commonly used ICU sedative agents around the world. Their unpredictable accumulation, however, with prolonged sedation as a consequence, has been recognized for a long time $[21,22]$. It was, therefore, natural that the short-acting anesthetic propofol would be introduced for ICU sedation with great enthusiasm and expectations. Though allowing rapid awakening after short-term use, propofol also appeared to unpredictably accumulate after long-term use and to cause prolonged sedation [23]. Soon after its introduction, a serious adverse effect, the propofol infusion syndrome (PRIS), was recognized [24]. As originally described [24], PRIS was characterized by rhabdomyolysis, hyperkalemia, metabolic acidosis, and renal and cardiac failure and is associated with a high mortality.

Despite many years of benzodiazepines and propofol use, few studies compared these medications [25] and only recently have they been evaluated for safety and efficacy in large randomized controlled trials. This has been a direct consequence of the introduction of dexmedetomidine for ICU sedation. Dexmedetomidine, a sedative with high $\alpha_{2}$-adrenoreceptor affinity and agonist action in the locus ceruleus, is the first sedative drug introduced for long-term ICU sedation to undergo formal evaluation for safety and efficacy according to modern drug development standards. This has necessitated comparisons with standard care sedation, and both midazolam and propofol have been used as comparators [26,27]. These trials have also provided insights into the comparative efficacy and safety profiles of these common sedatives. Dexmedetomidine has been shown to be non-inferior to both midazolam and propofol in maintaining light to moderate sedation $[26,27]$. It appears to shorten time to extubation and enhance arousability and patients' ability to communicate with caregivers. Dexmedetomidine may reduce delirium after long-term sedation as compared with midazolam [26] and also reduce the overall neurocognitive adverse 
events of sedation, such as agitation, anxiety, and delirium, when compared with propofol [27]. These trials excluded patients with severe kidney and liver disease, thus limiting the generalizability of the findings. Furthermore, known side effects (such as bradycardia) and the acquisition cost of dexmedetomidine remain a concern. The safety and efficacy of dexmedetomidine, however, have not been evaluated in some ICU patient groups, such as patients with acute neurologic disorder (for example, stroke and head trauma).

Inhaled anesthetic agents such as sevoflurane and isoflurane have been advocated for ICU sedation [28]. To avoid repeating the etomidate story, safety assessment according to current drug development standards is mandatory before introducing new drugs for ICU sedation [29]. At the moment, even the most basic experimental safety data on the long-term effects of prolonged administration of inhalational anesthetics are lacking.

\section{Sedative minimization and sedation depth}

About 15 years ago, Kollef and colleagues [21] reported the association of continuous intravenous sedation with prolonged mechanical ventilation. Soon after, Brook and colleagues [30] demonstrated a significantly shorter ventilation time and ICU and hospital stays with the use of a sedative-analgesic protocol compared with usual sedation care in medical ICU patients. Over the last decade, sedation minimization strategies, including protocolized sedation (PS), have become the focus of strong research interest.

PS, which appears to be a promising approach, depends on the bedside clinicians titrating the individual patient's sedation needs to match identified specific goals using routine structured assessments. In a pre-post study, protocolized analgesia and sedation resulted in reduced sedative and opioid doses and reduced ventilation and ICU times [31]. The success of PS, however, depends on local practices, nurse-to-patient ratios, and the intensity of nurse training and expertise. This may explain why PS was not associated with benefits in an Australian ICU environment where usual care was already oriented toward sedative minimization [32]. By means of a modified sedation scale with a defined sedation protocol, 129 post-operative patients were randomly assigned to either light or heavy sedation [33]. The light sedation group received lower midazolam and morphine doses associated with 1-day and 1.5-day mean reductions in ventilation time and ICU days, respectively.

Another way to minimize sedation may be the use of programmed sedation interruptions. Daily sedation interruption (DSI) recommended in the 2002 guidelines became a key strategy after Kress and colleagues [34] reported significant reductions in ventilation time and ICU stay in a single-center 128-patient randomized trial.
However, evaluation of DSI in subsequent randomized trials has produced inconsistent results. One trial was terminated early for safety concerns because the DSI group had a longer ventilation time and longer ICU and hospital lengths of stay compared with the sedation protocol group [35].

Girard and colleagues [36] combined DSI with daily spontaneous breathing trials (SBTs) in an open-label randomized trial and reported more days breathing without assistance and fewer days in the ICU and hospital and, although unexplained, suggested reduced mortality in the DSI/SBT group compared with the usual sedation care and SBT group. A limitation of this trial relates to a potential bias against the control group, given that sedatives were continued but not seemingly titrated to light sedation during the SBT, potentially leading to a longer ventilation time compared with the DSI group. Furthermore, unblinded research personnel were present during DSI in the trials by Kress and colleagues [34] and Girard and colleagues [36], creating serious potential for bias. In the trial by Girard and colleagues, the external validity of the experimental arm has also been questioned, given that the coordination of sedative titration with ventilator weaning is considered routine care in many ICUs outside the US and in many ICUs in North America.

Although DSI has many potential advantages (including the opportunity to cease infusions completely or to reduce dosage, perform a comprehensive neurological and delirium assessment, and assess for extubation readiness), it is not clear whether DSI offers any advantages when sedation is managed with a sedation protocol that targets light sedation. To address this question, Mehta and colleagues [37] conducted a multicenter randomized trial comparing PS with combined PS plus DSI in 423 critically ill mechanically ventilated medical and surgical patients. The authors found no difference in the primary outcome of duration of mechanical ventilation and no difference in ICU and hospital lengths of stay between the groups. Furthermore, the DSI group received higher daily opioid and benzodiazepines doses, and nurses reported higher workload with DSI. The enrolled patients, however, were primarily medical and were given benzodiazepines and this may reduce the generalizability of the findings. At present, although DSI appears to be safe, its effectiveness likely depends on the existing institutional sedation practice. If patients are kept lightly sedated, daily interruption does not appear to add further benefit and may increase nurse workload and drug use.

\section{Limitations of current sedation research}

The 2013 guidelines, albeit a comprehensive review of the evidence, uncovered a significant gap in our knowledge. Most clinical trials of sedation practice have been 
Table 1. Salient features of key sedation trials conducted in the last 15 years

\begin{tabular}{|c|c|c|c|c|c|c|c|}
\hline $\begin{array}{l}\text { Authors } \\
\text { (Year) }\end{array}$ & $\begin{array}{l}\text { Design } \\
\text { (Number) }\end{array}$ & $\begin{array}{l}\text { Time to } \\
\text { randomly } \\
\text { assign }\end{array}$ & $\begin{array}{l}\text { Main } \\
\text { inclusion }\end{array}$ & $\begin{array}{l}\text { Patients/intervention } \\
\text { versus control }\end{array}$ & $\begin{array}{l}\text { Time on } \\
\text { treatment }\end{array}$ & $\begin{array}{l}\text { Primary } \\
\text { outcome }\end{array}$ & Main results \\
\hline $\begin{array}{l}\text { Mehta et al. [37] } \\
(2012)\end{array}$ & $\begin{array}{l}\text { Multicenter RCT } \\
\text { open-label } \\
(423)\end{array}$ & 1 to 4 days & $\begin{array}{l}\text { Ventilated } \\
>48 \text { hours }\end{array}$ & $\begin{array}{l}\text { Medical } 80 \%+, \text { DSI + PS } \\
\text { versus PS. All patients } \\
\text { received MDZ and } \\
\text { received SBT. }\end{array}$ & $\begin{array}{l}\text { Until extubated } \\
\text { median } 7 \text { days }\end{array}$ & $\begin{array}{l}\text { Time to } \\
\text { extubation }\end{array}$ & $\begin{array}{l}\text { No difference in } \\
\text { outcomes }\end{array}$ \\
\hline $\begin{array}{l}\text { Jakob et al. [27] } \\
\text { (2012) }\end{array}$ & $\begin{array}{l}\text { Multicenter } \\
\text { two RCTs Double- } \\
\text { blind } \\
\text { (998, } 2 \text { studies) }\end{array}$ & $\begin{array}{l}48 \text { hours of } \\
\text { sedation }\end{array}$ & $\begin{array}{l}\text { Ventilated } \\
>48 \text { hours }\end{array}$ & $\begin{array}{l}\text { Medical Surgical and } \\
\text { Trauma } \\
\text { Dex versus MDZ and } \\
\text { Dex versus Propofol. All } \\
\text { patients DSI, SBT }\end{array}$ & $\begin{array}{l}\text { Median } 42(23-72) \\
\text { hours for Dex }\end{array}$ & $\begin{array}{l}\text { Time at target } \\
\text { sedation } \\
\text { RASS }-3 \text { to } 0\end{array}$ & $\begin{array}{l}\text { No difference in } \\
\text { primary outcome. } \\
\text { Shorter time to } \\
\text { extubation }\end{array}$ \\
\hline $\begin{array}{l}\text { Strøm et al. [14] } \\
(2010)\end{array}$ & $\begin{array}{l}\text { Single-center } \\
\text { Unblinded RCT } \\
\text { ( } 140 \text { but } 113 \\
\text { analyzed) }\end{array}$ & $\begin{array}{l}24 \text { hours after } \\
\text { intubation }\end{array}$ & $\begin{array}{l}\text { Ventilated } \\
>24 \text { hours }\end{array}$ & $\begin{array}{l}\text { General ICU patients } \\
\text { Morphine versus propofol } \\
\text { (first } 48 \text { hours) then MDZ. } \\
\text { DSI conducted in all } \\
\text { patients }\end{array}$ & $\begin{array}{l}\text { Not given. } \\
\text { Study staff } \\
\text { intervened 2-5 } \\
\text { days }\end{array}$ & $\begin{array}{l}\text { Ventilator-free } \\
\text { days at } 28 \text { days } \\
\text { after intubation }\end{array}$ & $\begin{array}{l}\text { More ventilator-free } \\
\text { days, shorter ICU } \\
\text { and hospital stays }\end{array}$ \\
\hline $\begin{array}{l}\text { Treggiari et al. } \\
\text { [33] (2009) }\end{array}$ & $\begin{array}{l}\text { Single-center } \\
\text { Open-label RCT } \\
\text { (129) }\end{array}$ & Up to 3 days & $\begin{array}{l}\text { Ventilated } \\
>12 \text { hours }\end{array}$ & $\begin{array}{l}\text { Mainly post-surgical } \\
(80 \%+) \\
\text { Light sedation versus } \\
\text { deep sedation using } \\
\text { Ramsay scale }\end{array}$ & $\begin{array}{l}\text { Mean days } \\
\text { Light } 2.9 \text { versus } \\
\text { deep } 5.5\end{array}$ & $\begin{array}{l}\text { Post-traumatic } \\
\text { stress at } 28 \text { days }\end{array}$ & $\begin{array}{l}\text { Trend to lower } \\
\text { post-traumatic } \\
\text { stress }\end{array}$ \\
\hline $\begin{array}{l}\text { Skrobic et al. } \\
\text { [31] (2010) }\end{array}$ & $\begin{array}{l}\text { Single-center } \\
\text { Pre and post } \\
(572 \text { and } 561)\end{array}$ & $\begin{array}{l}24 \text { hours after } \\
\text { ICU admission }\end{array}$ & $\begin{array}{l}\text { Admitted } \\
>24 \text { hours }\end{array}$ & $\begin{array}{l}\text { Protocolized analgesia } \\
\text { and sedation with } \\
\text { non-pharmacologic } \\
\text { intervention (music) }\end{array}$ & Through ICU stay & $\begin{array}{l}\text { Sedative and } \\
\text { analgesic needs }\end{array}$ & $\begin{array}{l}\text { Shorter ICU and } \\
\text { hospital stays, less } \\
\text { sub-syndromal } \\
\text { delirium }\end{array}$ \\
\hline $\begin{array}{l}\text { Riker et al. [26] } \\
\text { (2009) }\end{array}$ & $\begin{array}{l}\text { Multicenter RCT } \\
\text { double-blind } \\
(375 \text { at } 2: 1)\end{array}$ & Up to 96 hours & $\begin{array}{l}\text { Ventilated } \\
>24 \text { hours }\end{array}$ & $\begin{array}{l}\text { Medical } 85 \%+ \\
\text { Dex versus MDZ, rescue } \\
\text { MDZ } \\
\text { Sedation titration to RASS } \\
\text { Fentanyl opioid of choice }\end{array}$ & $\begin{array}{l}\text { Median days Dex } \\
3.5 \text { (2-5.2) versus } \\
\text { MDZ 4.1 (2.8-6.1) }\end{array}$ & $\begin{array}{l}\text { Time in target } \\
\text { RASS }-2 \text { to }+1\end{array}$ & $\begin{array}{l}\text { No difference in } \\
\text { RASS range. } \\
\text { Shorter ventilation } \\
\text { time and less } \\
\text { delirium }\end{array}$ \\
\hline $\begin{array}{l}\text { Girard et al. [30] } \\
(2008)\end{array}$ & $\begin{array}{l}\text { Multicenter RCT } \\
\text { Unblinded } \\
(335)\end{array}$ & 2.2 to 4 days & $\begin{array}{l}\text { Ventilated } \\
>12 \text { hours }\end{array}$ & $\begin{array}{l}\text { General ICU } \\
\text { SAT and SBT versus usual } \\
\text { sedation care and SBT } \\
\text { Research personnel } \\
\text { involved }\end{array}$ & $\begin{array}{l}\text { Time to pass SBT } \\
3.8(1-14) \\
3.9(1-11)\end{array}$ & $\begin{array}{l}\text { Ventilator-free } \\
\text { days }\end{array}$ & $\begin{array}{l}\text { More ventilator-free } \\
\text { days and lower } \\
\text { 12-month risk of } \\
\text { death }\end{array}$ \\
\hline $\begin{array}{l}\text { De Wit et al. [35] } \\
\text { (2008) }\end{array}$ & $\begin{array}{l}\text { Single-center RCT } \\
\text { unblinded } \\
(74)\end{array}$ & Not reported & $\begin{array}{l}\text { Ventilated in } \\
\text { medical ICU }\end{array}$ & $\begin{array}{l}\text { Medical respiratory ICU } \\
\text { DSI versus sedation } \\
\text { protocol }\end{array}$ & 6.7 (4-10) days & Ventilation time & $\begin{array}{l}\text { Terminated early; } \\
\text { higher mortality } \\
\text { longer vent time }\end{array}$ \\
\hline $\begin{array}{l}\text { Bucknall et al. } \\
\text { [32] (2008) }\end{array}$ & $\begin{array}{l}\text { Single-center } \\
\text { RCT unblinded } \\
(312)\end{array}$ & Not reported & $\begin{array}{l}\text { Ventilated in } \\
\text { ICU }\end{array}$ & $\begin{array}{l}\text { Medical/surgical/trauma } \\
\text { PS versus usual sedation } \\
\text { practice }\end{array}$ & $\begin{array}{l}\text { Ventilation hours } \\
79 \text { protocol } \\
59 \text { control }\end{array}$ & Ventilation time & $\begin{array}{l}\text { No difference in } \\
\text { outcomes }\end{array}$ \\
\hline $\begin{array}{l}\text { Pandharipande } \\
\text { et al. [40] (2007) }\end{array}$ & $\begin{array}{l}\text { 2-center RCT } \\
\text { double-blind } \\
\text { (106) }\end{array}$ & $\begin{array}{l}48 \text { hours after } \\
\text { mechanical } \\
\text { ventilation }\end{array}$ & $\begin{array}{l}\text { Ventilated } \\
>24 \text { hours }\end{array}$ & $\begin{array}{l}\text { Medical 70\%+/surgical } \\
\text { Dex versus lorazepam } \\
\text { Rescue propofol and } \\
\text { fentanyl }\end{array}$ & $\begin{array}{l}5 \text { (2-6) Dex versus } \\
4(2-6) \text { lorazepam }\end{array}$ & $\begin{array}{l}\text { Delirium-free } \\
\text { days, coma-free } \\
\text { days }\end{array}$ & $\begin{array}{l}\text { Higher coma-free } \\
\text { days but no effect } \\
\text { on delirium }\end{array}$ \\
\hline $\begin{array}{l}\text { Carson et al. [25] } \\
(2006)\end{array}$ & $\begin{array}{l}\text { 2-center RCT } \\
\text { Open-label } \\
\text { (132) } \\
\text { over } 56 \text { months }\end{array}$ & $\begin{array}{l}1.5 \text { days on } \\
\text { average after } \\
\text { ventilation }\end{array}$ & $\begin{array}{l}\text { Ventilated } \\
>48 \text { hours + } \\
\text { lorazepam } \\
>10 \mathrm{mg} / \\
\text { hour }\end{array}$ & $\begin{array}{l}\text { Medical ICU patients } \\
\text { Lorazepam boluses versus } \\
\text { propofol infusion with DSI }\end{array}$ & $\begin{array}{l}\text { Not reported. } \\
\text { Ventilation times } \\
5.8 \text { versus } \\
8.4 \text { days } \\
\text { lorazepam }\end{array}$ & Ventilation time & $\begin{array}{l}\text { Shorter ventilation } \\
\text { time and ICU stay, } \\
\text { more ventilation- } \\
\text { free days }\end{array}$ \\
\hline $\begin{array}{l}\text { Kress et al. [34] } \\
(2000)\end{array}$ & $\begin{array}{l}\text { Single-center RCT } \\
\text { unblinded } \\
(128)\end{array}$ & $\begin{array}{l}\text { Ventilated } \\
\text { patients }\end{array}$ & $\begin{array}{l}\text { Ventilated } \\
>48 \text { hours } \\
\text { and sedated }\end{array}$ & $\begin{array}{l}\text { Medical ICU } \\
\text { DSI started } 48 \text { hours after } \\
\text { enrollment versus usual } \\
\text { care. Research personnel } \\
\text { involved }\end{array}$ & $\begin{array}{l}\text { Not reported. } \\
\text { Ventilation times } \\
4.9 \text { versus } \\
7.3 \text { days }\end{array}$ & $\begin{array}{l}\text { Ventilation and } \\
\text { ICU time }\end{array}$ & $\begin{array}{l}\text { Reduced ventilation } \\
\text { time and ICU stay }\end{array}$ \\
\hline $\begin{array}{l}\text { Brook et al. [30] } \\
\text { (1999) }\end{array}$ & $\begin{array}{l}\text { Single-center RCT } \\
\text { unblinded } \\
(321)\end{array}$ & $\begin{array}{l}\text { Ventilated } \\
\text { and in ICU } \\
>24 \text { hours }\end{array}$ & $\begin{array}{l}\text { Ventilated } \\
>24 \text { hours }\end{array}$ & $\begin{array}{l}\text { Medical ICU patients } \\
\text { sedated with lorazepam. } \\
\text { Nurse-implemented PS } \\
\text { versus usual care }\end{array}$ & $\begin{array}{l}3.5(4) \text { days in } \\
\text { protocol versus } \\
5.6(6.4) \text { days } \\
\text { controls }\end{array}$ & Ventilation time & $\begin{array}{l}\text { Shorter ventilation } \\
\text { time and ICU stay }\end{array}$ \\
\hline
\end{tabular}

Dex, dexmedetomidine; DSI, daily sedative interruption; ICU, intensive care unit; MDZ, midazolam; PS, protocolized sedation; RASS, Richmond Agitation Sedation Scale; RCT, randomized controlled trial; SAT, spontaneous awakening trial; SBT, spontaneous breathing trial. 
inadequately powered and have not accounted for intensity of bedside care and thus lack external validity $[14,33,34,38]$. In addition, most shared significant limitations (Table 1). First, control groups did not reliably match current best practice, leading to misalignment with current practice. As such, these studies are seen to lack both relevance and validity. Second, clinical trials evaluating sedative agents have focused on comparisons of drug A and B, although patients are often sedated with a combination of drugs $[26,27]$. Third, the use of sedation monitoring and delirium assessment were not reliably applied. Fourth, random assignment did not occur until up to 96 hours after initiation of mechanical ventilation, leading to significant pre-enrolment sedative prescription, reduced duration of protocolized intervention, and reduced treatment separation between the experimental and control groups $[26,27,34]$. Fifth, few studies have assessed long-term patient-centered outcomes [36]. Sixth, the intervention was sometimes administered by research staff rather than clinical staff, thus limiting generalizability $[33,34,36]$. Finally, sedation strategy may have an impact on mortality $[19,31,36]$; however, there have not been any large phase III trials using mortality as the primary outcome. All of these aspects have resulted in a lack of conclusive evidence to guide clinicians in their daily practice and, thus, in variable adoption of many of the above interventions outside participating research centers. These problems are of particular relevance to delirium, and there is ongoing uncertainty regarding best preventive measures and management [12].

Delirium received significant attention in the 2013 Pain, Agitation, and Delirium (PAD) guidelines. The guidelines emphasized the value of light sedation, whenever clinically appropriate, as a possible way of preventing or attenuating delirium. None of the randomized trials comparing lighter and deeper sedation, however, led to a reduction in delirium with light sedation $[14,36,37]$. Recent data have also questioned the presumed link between drug-induced coma, deep sedation, and delirium $[2,3,39]$.

\section{The future of intensive care unit sedation research}

To bridge the evidence gap, an evolutionary approach to sedation research is needed. A structured research program that describes current practice in detail and identifies possible modifiable risk factors is an important first step. Such multinational multicenter longitudinal cohort assessments of sedation practice have revealed a high prevalence of deep sedation early after initiation of mechanical ventilation; early deep sedation was strongly and independently associated with delayed extubation and long-term mortality (but not delirium) [2,3]. It is, therefore, imperative that any future intervention have specific key characteristics. First, it should be given early within minutes to hours of commencing sedation or mechanical ventilation. Second, the control group should align with best practice for the purpose of achieving relevance and external validity. Third, an integrated process of care (rather than specific drug A versus B) targeting light sedation should be investigated. Finally, investigators should use sedative agents shown to promote arousability, reduce ventilation duration, and attenuate delirium $[26,27,40]$. An innovative sedation strategy has been termed early goal-directed sedation and was recently tested for feasibility and safety in a pilot randomized trial [41]. This study suggested that early deep sedation, which was not addressed in any previous randomized trials, may be harmful and largely unjustified. The early goal-directed sedation concept will now be tested in an adequately powered, multinational multicenter randomized trial with a patient-centered outcome [42]. This trial will seek to address several of the key limitations and uncertainties of prior sedation research and current practice.

We acknowledge the comprehensive nature of the 2013 PAD guidelines; we believe they do provide a framework to adapt sedation practices to suit local and institutional needs. The guidelines have been appropriately nonprescriptive, and considering the limitations of many studies supporting PAD recommendations, we should be cautious about implementing strategies that are designed to force untested intervention bundles (that are based on a small number of randomized trials) into general practice. The second decade of the 21 st century should be the decade of establishing high-level evidence for ICU sedation practice. The need is great, the time is right, the time is now.

\section{Abbreviations}

DSI, daily sedation interruption; ICU, intensive care unit; PAD, Pain, Agitation, and Delirium; PRIS, propofol infusion syndrome; PS, protocolized sedation; SBT, spontaneous breathing trial.

\section{Competing interests}

YS has received unrestricted grant-in-aid research grants from Hospira Inc. (Lake Forest, IL, USA) and research grants from Roche Diagnostics (Melbourne, Australia) and Thermo Fisher Scientific Inc. (Melbourne, Australia). Speakers' honoraria from Hospira Inc. and Roche Diagnostics were paid to YS's research fund. JT's department, the Department of Intensive Care Medicine of University Hospital Bern, has, or has had in the past, research contracts with Abbott Nutrition International (Abbott AG) (Baar, Switzerland), B. Braun Medical AG (Sempach, Switzerland), CSEM SA (Neuchâtel, Switzerland), Edwards Lifesciences Corporation (Irvine, CA, USA), Kenta Biotech Ltd (ZürichSchlieren, Switzerland), Maquet Critical Care AB (Solna, Sweden), Omnicare Clinical Research AG (Oberwil, Switzerland), and Orion Corporation (Espoo, Finland) and research and development/consulting contracts with Edwards Lifesciences Corporation, Maquet Critical Care AB, Baxter Healthcare SA (Glattpark (Opfikon), Switzerland), and Nestlé (Vevey, Switzerland). The money is or was paid into a departmental fund. JT has received no personal financial gain. The department has received unrestricted educational grants from the following organizations for organizing a quarterly postgraduate educational symposium, the Berner Forum for Intensive Care: Fresenius Kabi (Schweiz) AG (Oberdorf, Switzerland), GlaxoSmithKline AG (Münchenbuchsee, Switzerland), 
MSD AG (Luzern, Switzerland), Eli Lilly (Suisse) S.A. (Vernier, Switzerland), Baxter AG (Volketswil, Switzerland), Astellas Pharma AG (Wallisellen, Switzerland), AstraZeneca AG (Zug, Switzerland), B. Braun Medical AG (Sempach, Switzerland), CSL Behring AG (Bern, Switzerland), Maquet AG (Gossau, Switzerland), Novartis Pharma Schweiz AG (Basel, Switzerland), Covidien Schweiz AG (Wollerau, Switzerland), Nycomed Pharma AG (Dübendorf, Switzerland), Pfizer AG (Zürich, Switzerland), and Robapharm AG (Allschwil, Switzerland). RR has received research support from Hospira Inc., AstraZeneca, and Covidien. RB and SM declare that they have no competing interests.

\section{Authors' contributions}

YS contributed the concept, general outline, the manuscript plan, and final drafting of manuscript. Each author wrote an assigned section of the manuscript and critically reviewed and approved the final manuscript.

\section{Author details}

'University of New South Wales Clinical School, Prince of Wales Hospital, Barker Street, Randwick, NSW 2035, Australia, Australia. 'Faculty of Medicine, University of Melbourne, Melbourne, Department Intensive Care Medicine, The Austin Hospital, 145 Studley Road, Heidelberg, Victoria 3084, Australia. ${ }^{3}$ Medical/Surgical ICU, Mount Sinai Hospital, 600 University Avenue \#18216, Toronto, ON, Canada, M5G 1X5. ${ }^{4}$ Tufts University School of Medicine, Neuroscience Institute and Department of Critical Care Medicine, Maine Medical Center, 22 Bramhall Street, Portland, ME 04102, USA. ${ }^{5}$ Department of Intensive Care Medicine, University Hospital Bern (Inselspital), CH-3010 Bern, Switzerland.

Published: 12 June 2013

\section{References}

1. Patel SB, Kress JP: Sedation and analgesia in the mechanically ventilated patient. Am J Respir Crit Care Med 2012, 185:486-497.

2. Shehabi Y, Bellomo R, Reade MC, Bailey M, Bass F, Howe B, McArthur CJ, Seppelt IM, Webb SA, Weisbrodt L: Early intensive care sedation predicts long-term mortality in ventilated critically ill patients. Am J Respir Crit Care Med 2012, 186:724-731.

3. Shehabi Y, Chan L, Kadiman S, Alias A, Ismail WN, Tan MA, Khoo TM, Ali SB, Saman MA, Shaltut A, Tan CC, Yong CY, Bailey M; Sedation Practice in Intensive Care Evaluation (SPICE) Study Group investigators: Sedation depth and long-term mortality in mechanically ventilated critically ill adults: a prospective longitudinal multicentre cohort study. Intensive Care Med 2013, 39:910-918

4. Mehta S, McCullagh I, Burry L: Current sedation practices: lessons learned from international surveys. Crit Care Clin 2009, 25:471-488.

5. Reade MC, Eastwood GM, Peck L, Bellomo R, Baldwin I: Routine use of the confusion assessment method for the intensive care unit (CAM-ICU) by bedside nurses may underdiagnose delirium. Crit Care Resusc 2011, 13:217-224.

6. Shehabi Y: The search for the holy grail: diagnosing delirium in the intensive care unit. Crit Care Resusc 2011, 13:214.

7. Hansen-Flaschen JH, Brazinsky S, Basile C, Lanken PN: Use of sedating drugs and neuromuscular blocking agents in patients requiring mechanical ventilation for respiratory failure. JAMA 1991, 266:2870-2875.

8. Shapiro BA, Warren J, Egol AB, Greenbaum DM, Jacobi J, Nasraway SA, Schein RM, Spevetz A, Stone JR: Practice parameters for intravenous analgesia and sedation for adult patients in the intensive care unit: an executive summary. Crit Care Med 1995, 23:1596-1600.

9. Jacobi J, Fraser GL, Coursin DB, Riker RR, Fontaine D, Wittbrodt ET, Chalfin DB, Masica MF, Bjerke HS, Coplin WM: Clinical practice guidelines for the sustained use of sedatives and analgesics in the critically ill adult. Crit Care Med 2002, 30:1 19-141.

10. Martin J, Heymann A, Bäsell K, Baron R, Biniek R, Bürkle H, Dall P, Dictus C, Eggers V, Eichler I, Engelmann L, Garten L, Hartl W, Haase U, Huth R, Kessler P, Kleinschmidt S, Koppert W, Kretz FJ, Laubenthal H, Marggraf G, Meiser A, Neugebauer E, Neuhaus U, Putensen C, Quintel M, Reske A, Roth B, Scholz J, Schröder $S$, et al.: Evidence and consensus-based German guidelines for the management of analgesia, sedation and delirium in intensive care short version. Ger Med Sci 2010, 8:Doc02.

11. Sauder P, Andreoletti M, Cambonie G, Capellier G, Feissel M, Gall O, GoldranToledano D, Kierzek G, Mateo J, Mentec H, Mion G, Rigaud JP, Seguin P: [Sedation and analgesia in intensive care (with the exception of new-born babies). French Society of Anesthesia and Resuscitation. French-speaking Resuscitation Society]. Ann Fr Anesth Reanim 2008, 27:541-551. Article in French.

12. Barr J, Fraser GL, Puntillo K, Ely EW, Gélinas C, Dasta JF, Davidson JE, Devlin JW, Kress JP, Joffe AM: Clinical practice guidelines for the management of pain, agitation, and delirium in adult patients in the intensive care unit. Crit Care Med 2013, 41:263-306.

13. Riker RR, Fraser GL: Altering intensive care sedation paradigms to improve patient outcomes. Crit Care Clin 2009, 25:527.

14. Strøm T, Martinussen T, Toft P: A protocol of no sedation for critically ill patients receiving mechanical ventilation: a randomised trial. Lancet 2010, 375:475-480.

15. Scholz J, Steinfath M, Schulz M: Clinical pharmacokinetics of alfentanil, fentanyl and sufentanil. An update. Clin Pharmacokinet 1996, 31:275.

16. McQuay H: Opioid clinical pharmacology and routes of administration. BrMed Bull 1991, 47:703-717.

17. Limn JK, Stanley TH, Eisele J, Webster L, Woodward A: High dose fentanyl anesthesia for coronary artery surgery plasma fentanyl concentrations and influence of nitrous oxide on cardiovascular responses. Anesth Analg 1979, 58:390-395.

18. Saarenmaa E, Huttunen P, Leppäluoto J, Meretoja O, Fellman V: Advantages of fentanyl over morphine in analgesia for ventilated newborn infants after birth: a randomized trial. J Pediatr 1999, 134:144-150.

19. Ledingham IMA, Watt I: Influence of sedation on mortality in critically ill multiple trauma patients. Lancet 1983, 1:1270.

20. Albert SG, Ariyan S, Rather A: The effect of etomidate on adrenal function in critical illness: a systematic review. Intensive Care Med 2011, 37:901-910.

21. Kollef MH, Levy NT, Ahrens TS, Schaiff R, Prentice D, Sherman G: The use of continuous iv sedation is associated with prolongation of mechanical ventilation. Chest 1998, 114:541-548.

22. Koch-Weser J, Greenblatt DJ, Shader RI, Abernethy DR: Current status of benzodiazepines. N Engl J Med 1983, 309:354-358.

23. Barr J, Egan TD, Sandoval NF, Zomorodi K, Cohane C, Gambus PL, Shafer SL: Propofol dosing regimens for ICU sedation based upon an integrated pharmacokinetic-pharmacodynamic model. Anesthesiology 2001, 95:324-333.

24. Roberts RJ, Barletta JF, Fong JJ, Schumaker G, Kuper PJ, Papadopoulos S, Yogaratnam D, Kendall E, Xamplas R, Gerlach AT: Incidence of propofolrelated infusion syndrome in critically ill adults: a prospective, multicenter study. Crit Care 2009, 13:R169.

25. Carson SS, Kress JP, Rodgers JE, Vinayak A, Campbell-Bright S, Levitt J, Bourdet S, Ivanova A, Henderson AG, Pohlman A: A randomized trial of intermittent lorazepam versus propofol with daily interruption in mechanically ventilated patients. Crit Care Med 2006, 34:1326-1332.

26. Riker RR, Shehabi Y, Bokesch PM, Ceraso D, Wisemandle W, Koura F, Whitten P, Margolis BD, Byrne DW, Ely EW, Rocha MG; SEDCOM (Safety and Efficacy of Dexmedetomidine Compared With Midazolam) Study Group: Dexmedetomidine vs. midazolam for sedation of critically ill patients: a randomized trial. JAMA 2009, 301:11

27. Jakob SM, Ruokonen E, Grounds RM, Sarapohja T, Garratt C, Pocock SJ, Bratty JR, Takala J; Dexmedetomidine for Long-Term Sedation Investigators: Dexmedetomidine vs midazolam or propofol for sedation during prolonged mechanical ventilation: two randomized controlled trials. JAMA 2012, 307:10.

28. Sackey PV, Martling C-R, Granath F, Radell PJ: Prolonged isoflurane sedation of intensive care unit patients with the anesthetic conserving device. Crit Care Med 2004, 32:2241-2246.

29. Bracco D, Donatelli F: Volatile agents for ICU sedation? Intensive Care Med 2011, 37:895-897.

30. Brook AD, Ahrens TS, Schaiff R, Prentice D, Sherman G, Shannon W, Kollef MH: Effect of a nursing-implemented sedation protocol on the duration of mechanical ventilation. Crit Care Med 1999, 27:2609-2615.

31. Skrobik Y, Ahern S, Leblanc M, Marquis F, Awissi DK, Kavanagh BP: Protocolized intensive care unit management of analgesia, sedation, and delirium improves analgesia and subsyndromal delirium rates. Anesth Analg 2010, 111:451-463.

32. Bucknall TK, Manias E, Presneill Jj: A randomized trial of protocol-directed sedation management for mechanical ventilation in an Australian intensive care unit. Crit Care Med 2008, 36:1444-1450.

33. Treggiari MM, Romand JA, Yanez ND, Deem SA, Goldberg J, Hudson L, Heidegger CP, Weiss NS: Randomized trial of light versus deep sedation on 
mental health after critical illness. Crit Care Med 2009, 37:2527.

34. Kress JP, Pohlman AS, O'Connor MF, Hall JB: Daily interruption of sedative infusions in critically ill patients undergoing mechanical ventilation. NEngl J Med 2000, 342:1471-1477.

35. De Wit M, Gennings C, Jenvey WI, Epstein SK: Randomized trial comparing daily interruption of sedation and nursing-implemented sedation algorithm in medical intensive care unit patients. Crit Care 2008, 12:R70

36. Girard TD, Kress JP, Fuchs BD, Thomason JWW, Schweickert WD, Pun BT, Taichman DB, Dunn JG, Pohlman AS, Kinniry PA: Efficacy and safety of a paired sedation and ventilator weaning protocol for mechanically ventilated patients in intensive care (Awakening and Breathing Controlled trial): a randomised controlled trial. Lancet 2008, 371:126-134.

37. Mehta S, Burry L, Cook D, Fergusson D, Steinberg M, Granton J, Herridge M, Ferguson N, Devlin J, Tanios M: Daily sedation interruption in mechanically ventilated critically ill patients cared for with a sedation protocol: a randomized controlled trial. JAMA 2012, 308:1985-1992.

38. Schweickert WD, Pohlman MC, Pohlman AS, Nigos C, Pawlik AJ, Esbrook CL, Spears L, Miller M, Franczyk M, Deprizio D: Early physical and occupational therapy in mechanically ventilated, critically ill patients: a randomised controlled trial. Lancet 2009, 373:1874-1882.

39. Skrobik Y, Leger C, Cossette M, Michaud V, Turgeon J: Factors predisposing to coma and delirium: fentanyl and midazolam exposure; CYP3A5, ABCB1, and $A B C G 2$ genetic polymorphisms; and inflammatory factors. Crit Care Med 2013, 41:999-1008.

40. Pandharipande PP, Pun BT, Herr DL, Maze M, Girard TD, Miller RR, Shintani AK, Thompson JL, Jackson JC, Deppen SA: Effect of sedation with dexmedetomidine vs lorazepam on acute brain dysfunction in mechanically ventilated patients. JAMA 2007, 298:2644-2653.

41. Shehabi Y, Bellomo R, Reade MC, Bailey M, Bass F, Howe B, McArthur CJ, Seppelt IM, Webb SA, Weisbrodt L: Early goal directed sedation vs standard care sedation in mechanically ventilated critically ill patients, randomized controlled trial. Crit Care Med 2013, in press.

42. Shehabi Y: Early goal directed sedation vs standard care in mechanically ventilated critically ill patients

[http://clinicaltrials.gov/ct2/show/NCT01728558].

doi:10.1186/cc12679

Cite this article as: Shehabi $Y$, et al:: Intensive care sedation: the past, present and the future. Critical Care 2013, 17:322. 